\title{
Stability and preservation of a new formulation of epoprostenol sodium for treatment of pulmonary arterial hypertension
}

This article was published in the following Dove Press journal:

Drug Design, Development and Therapy

14 September 2012

Number of times this article has been viewed

\section{Olivier Lambert \\ Dirk Bandilla}

Actelion Pharmaceuticals Ltd, Allschwil, Switzerland
Correspondence: Olivier Lambert Actelion Pharmaceuticals Ltd, Gewerbestrasse 16, CH-4I23, Allschwil, Switzerland Tel +4I6 I565 675I

Fax +4I6 I565 6366

Email olivier.lambert@actelion.com
Background: The aim of this study was to evaluate the stability and microbiological properties of a formulation of epoprostenol sodium with L-arginine and sucrose excipients (epoprostenol AS).

Methods: The stability of the reconstituted solutions after storage at $5^{\circ} \mathrm{C}$ and $25^{\circ} \mathrm{C}$, diluted solutions $(3000-60,000 \mathrm{ng} / \mathrm{mL})$ at controlled room temperature, and diluted solutions (3000$60,000 \mathrm{ng} / \mathrm{mL}$ ) stored at $5^{\circ} \mathrm{C}$ and then at room temperature were evaluated. Solutions were prepared using sterile water for injection or sterile saline (sodium chloride $0.9 \%$ ) for injection. Shelf-life was assessed by determining potency over time relative to initial potency. In this context, potency is synonymous with content. The antimicrobial activity of reconstituted $(100,000 \mathrm{ng} / \mathrm{mL}$ for $0.5 \mathrm{mg}$ vial, $300,000 \mathrm{ng} / \mathrm{mL}$ for $1.5 \mathrm{mg}$ vial) and diluted $(3000 \mathrm{ng} / \mathrm{mL})$ epoprostenol AS was measured using an antimicrobial effectiveness test after inoculation with six species of bacteria, yeast, and mold.

Results: Reconstituted epoprostenol AS was stable for up to one day's storage at $25^{\circ} \mathrm{C}$ or 7 days' storage at $5^{\circ} \mathrm{C}$. Epoprostenol AS was stable for up to 72 hours when diluted, depending on temperature and concentration. The maximum shelf-life of the diluted solution if the reconstituted solution had been stored for up to one day at room temperature or up to 7 days at $5^{\circ} \mathrm{C}$, was between 24 and 72 hours, depending on concentration. Following storage of diluted solutions at $5^{\circ} \mathrm{C}$ for up to 8 days, maximum shelf-life was between one and 2 days, depending on temperature and concentration. Potency was not dependent on diluents. Preservative testing confirmed no microbial growth for any of six organisms tested for at least 14 days at $5^{\circ} \mathrm{C}$ or $25^{\circ} \mathrm{C}$ for the reconstituted solution and for at least 16 days at $5^{\circ} \mathrm{C}$ followed by one day at $25^{\circ} \mathrm{C}$ for the diluted solutions.

Conclusion: Epoprostenol AS has favorable thermal stability and does not support the growth of any micro-organism tested for up to 17 days. This extended stability under ambient conditions has the potential to improve convenience further for patients.

Keywords: epoprostenol, pulmonary arterial hypertension, potency, stability, shelf-life, microbiological activity

\section{Introduction}

We have recently reported on the stability and microbial properties of Veletri ${ }^{\circledR}$ (Actelion Pharmaceuticals Ltd, Allschwil, Switzerland), a formulation of epoprostenol sodium with arginine and mannitol excipients (epoprostenol AM), and prolonged stability at room temperature. ${ }^{1}$ Epoprostenol AM has been indicated for the long-term intravenous treatment of pulmonary arterial hypertension in the US since April 2008.

Pulmonary arterial hypertension is a severe disease characterized by a progressive elevation of pulmonary artery pressure and pulmonary vascular resistance, leading to 
right ventricular failure and death. ${ }^{2}$ Patients with pulmonary arterial hypertension require lifelong therapy. ${ }^{3}$ Intravenous epoprostenol sodium with glycine and mannitol excipients (epoprostenol GM, Flolan ${ }^{\circledR}$, GlaxoSmithKline, London, UK) has also been used to treat pulmonary arterial hypertension for a number of years. However, its use is complicated by a lack of stability in aqueous solution which impacts on storage and administration of the drug when used in a clinical situation. The main degradation route for epoprostenol is hydrolysis to 6-keto-prostaglandin $\mathrm{F}_{1 \alpha}$ (6-keto-PGF1 $\alpha$ ), which is accelerated by higher temperature and low $\mathrm{pH}^{4}$ Therefore, limiting degradation in aqueous solution relies on reducing temperature and/or increasing the $\mathrm{pH}$. The need for low temperatures to improve stability means that ice packs must be used during clinical administration; alternatively, the medication cassette needs to be changed frequently. ${ }^{5,6}$ Both procedures result in considerable inconvenience to the patient. Moreover, frequent changes of the medication cassette increase the risk of blood stream infections.

Improved thermal stability of epoprostenol AM was achieved by replacement of glycine with L-arginine to give a higher $\mathrm{pH}$ in solution. In stability studies, epoprostenol AM reconstituted and immediately diluted to the required concentration with either sterile water for injection or sterile saline (sodium chloride $0.9 \%$ ) for injection was stable for up to 3 days at $25^{\circ} \mathrm{C}$ and up to 7 days at $5^{\circ} \mathrm{C}$, depending on the concentration. ${ }^{1}$ Diluted epoprostenol AM was also shown to be a self-preserving system which did not support microbial growth.

The prolonged stability of epoprostenol AM could result in improved convenience for clinicians, patients, and caregivers in terms of ease of use (extended storage of reconstituted and diluted solutions, no need for ice packs during clinical administration, ability to dilute using nonproprietary diluents).

Since its initial development, further improvements have been made to optimize the formulation of epoprostenol AM. These include the replacement of mannitol with sucrose for stability of the lyophilized cake during storage, and the provision of a vial containing $0.5 \mathrm{mg}$ of compound in addition to a vial containing $1.5 \mathrm{mg}$ of compound. The current study aimed to investigate the stability of this second formulation of epoprostenol sodium with L-arginine and sucrose excipients (epoprostenol AS, soon to be available as both $0.5 \mathrm{mg}$ and $1.5 \mathrm{mg}$ dose strengths), under conditions which reflect its use in clinical practice and the potential needs of patients and physicians, including storage of the reconstituted solution prior to dilution and administration at room temperature; immediate reconstitution, dilution, and administration at room temperature; and storage of diluted solutions prior to administration at room temperature. The antimicrobial properties of the diluted solutions were also tested.

\section{Materials and methods Formulation}

Epoprostenol AS is formulated as a sterile lyophilized powder for reconstitution, packaged in a $10 \mathrm{~mL}$ glass vial with a $20 \mathrm{~mm}$ rubber stopper. In addition to epoprostenol sodium $0.5 \mathrm{mg}$ vial or $1.5 \mathrm{mg}$ vial, the new formulation contains L-arginine at $50 \mathrm{mg}$ vial (buffering agent), sucrose at $100 \mathrm{mg}$ vial (bulking agent), and sodium hydroxide (to adjust for $\mathrm{pH})$.

\section{Stability studies}

To assess the stability of reconstituted solutions of epoprostenol AS, $0.5 \mathrm{mg}$ and $1.5 \mathrm{mg}$ vials reconstituted with $5 \mathrm{~mL}$ sterile water for injection or sterile saline for injection were stored in cassettes at $5^{\circ} \mathrm{C}$ or $25^{\circ} \mathrm{C}$ for $0,1,4$, or 7 days.

To assess the stability of the diluted solutions under conditions reflecting the clinical use of immediate administration, $0.5 \mathrm{mg} / \mathrm{mL}$ and $1.5 \mathrm{mg} / \mathrm{mL}$ vials of epoprostenol AS were reconstituted with $5 \mathrm{~mL}$ sterile water for injection or sterile saline for injection and immediately diluted in the same diluents to give a range of concentrations $(3000,15,000$ or $60,000 \mathrm{ng} / \mathrm{mL})$ and stored in $100 \mathrm{~mL}$ $\mathrm{CADD}^{\mathrm{TM}}$ medication cassette reservoirs (polyvinyl chloride reservoir; Smiths Medical MD Inc, St Paul, MN). Solutions were kept at controlled temperature conditions $\left(25^{\circ} \mathrm{C}, 30^{\circ} \mathrm{C}\right.$, or $40^{\circ} \mathrm{C}$ ) and aliquots were removed for potency testing either immediately ( 0 hours) or 12, 24, 48, or 72 hours after storage in the cassette depending on concentration (Table 1). Final concentrations were chosen to reflect the minimum, medium, and maximum concentrations used in clinical practice.

To assess stability following the storage of diluted solutions, diluted samples were prepared as described above and initially stored in the medication cassettes at $5^{\circ} \mathrm{C}$ for 0 , 1 , or 8 days. Solutions were subsequently stored under controlled temperature conditions $\left(25^{\circ} \mathrm{C}\right.$ or $\left.30^{\circ} \mathrm{C}\right)$ for 24 or 48 hours before potency testing (Table 2 ). These conditions reflected the clinical use of storing diluted solutions prior to administration.

As a measure of stability, the potency of epoprostenol AS over time relative to initial potency at time zero (expressed as a percentage) was determined for all conditions of storage. Potency was determined by high-performance liquid chromatography with a Gemini-NX C18, $3 \mu \mathrm{m}, 110 \AA$, 
Table I Stability assessment protocol and storage conditions tested for solutions of epoprostenol AS diluted using sterile water for injection or sterile saline (sodium chloride $0.9 \%$ ) for injection which reflect the clinical situation of immediate administration

\begin{tabular}{llll}
\hline Strength & $\begin{array}{l}\text { Concentration } \\
\text { of diluted solution }\end{array}$ & Temperature & $\begin{array}{l}\text { Time } \\
\text { intervals } \\
\text { (hours) }\end{array}$ \\
\hline $0.5 \mathrm{mg}$ vial & $3000 \mathrm{ng} / \mathrm{mL}$ & $25^{\circ} \mathrm{C}$ & $0,12,24,48$ \\
& & $30^{\circ} \mathrm{C}$ & $0,12,24,48$ \\
$1.5 \mathrm{mg}$ vial & $15,000 \mathrm{ng} / \mathrm{mL}$ & $40^{\circ} \mathrm{C}$ & $0,4,8,12$ \\
& & $25^{\circ} \mathrm{C}$ & $0,12,24,48$ \\
& $30^{\circ} \mathrm{C}$ & $0,12,24,48$ \\
& $60,000 \mathrm{ng} / \mathrm{mL}$ & $40^{\circ} \mathrm{C}$ & $0,4,8,12,24$ \\
& & $25^{\circ} \mathrm{C}$ & $0,12,24,48,72$ \\
& & $30^{\circ} \mathrm{C}$ & $0,12,24,48$ \\
& & $40^{\circ} \mathrm{C}$ & $0,4,8,12,24$ \\
\hline
\end{tabular}

Abbreviation: AS, arginine-sucrose.

$150 \times 3 \mathrm{~mm}$ column (Phenomenex, Torrance, CA) using a borate buffer/acetonitrile gradient, with injection volumes ranging from $25 \mu \mathrm{L}$ to $100 \mu \mathrm{L}$ and a detection wavelength of $205 \mathrm{~nm}$ for reconstituted solutions and $198 \mathrm{~nm}$ for all subsequent dilutions. This method has been validated with respect to specificity, linearity, precision, and accuracy (Bandilla et al, unpublished results). Levels of related substances were also determined, including 6-keto-PGF1 $\alpha$. Shelflife was assessed by determining the period of time over which a potency $\geq 90 \%$ was maintained relative to initial potency at time zero. The $\mathrm{pH}$ of the reconstituted and diluted solutions, taken at each study point, was measured using a Uniprobe Pt 1000 glass electrode (Metrohm, Zolfingen, Switzerland).

\section{Preservative effectiveness testing}

Cultures of the bacteria Staphylococcus aureus, Pseudomonas aeruginosa, Escherichia coli, and Clostridium sporogenes, the yeast Candida albicans, and the mold Aspergillus niger (Remel Quanti-Cult Plus, Thermo Fisher Scientific, Lenexa, KS) were prepared as per the manufacturer's instructions and used within 24 hours of preparation. An initial plate count using each microbial suspension was performed to confirm appropriate levels of micro-organisms ( $<10$ colony forming units $[\mathrm{CFU}] / \mathrm{mL}$ ) as follows. Each microbial suspension was plated into sterile Petri dishes in duplicate. Using the pour plate method, bacteria were plated with tempered microbial content test agar and yeast and mold with tempered Sabouraud dextrose agar. Plates were incubated for $3-5$ days at $30^{\circ} \mathrm{C}-35^{\circ} \mathrm{C}$ for bacteria and $20^{\circ} \mathrm{C}-25^{\circ} \mathrm{C}$ for the yeast and mold $(C$. sporogenes was incubated under anaerobic conditions).

To assess the effectiveness of the preservative in epoprostenol AS $0.5 \mathrm{mg}$ vials were reconstituted as above. Samples were inoculated with $<10 \mathrm{CFU} / \mathrm{mL}$ of each microbial suspension and the contents mixed to homogenize. Samples were stored for up to 14 days at $5^{\circ} \mathrm{C}$ or $25^{\circ} \mathrm{C}$, and $1 \mathrm{~mL}$ aliquots were removed at time 0 , and on days $1,4,7$, and 14 , plated, and incubated for $3-5$ days at $30^{\circ} \mathrm{C}-35^{\circ} \mathrm{C}$ for bacteria and $20^{\circ} \mathrm{C}-25^{\circ} \mathrm{C}$ for mold and yeast prior to counting. The number of CFU present for each organism after each interval was determined and the log reduction was calculated.

To assess the effectiveness of the preservative in the diluted solution, $3 \mathrm{~mL}$ of reconstituted solution was further diluted to $100 \mathrm{~mL}$ (final dilution $3000 \mathrm{ng} / \mathrm{mL}$ ) and inoculated with $<10 \mathrm{CFU} / \mathrm{mL}$ of each microbial suspension as described above. Samples were stored for up to 16 days at $5^{\circ} \mathrm{C}$ followed by up to 48 hours at $25^{\circ} \mathrm{C}$ and $60 \%$ relative humidity. Further samples were also stored for up to 48 hours at $40^{\circ} \mathrm{C}$ and $75 \%$ relative humidity. Next, $1 \mathrm{~mL}$ aliquots were plated and incubated, and CFU counted as described above. Microbial growth was considered evident when the

Table 2 Stability assessment protocol of solutions of epoprostenol AS diluted using sterile water for injection or sterile saline (sodium

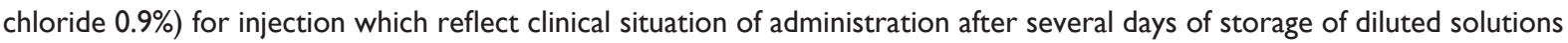

\begin{tabular}{|c|c|c|c|c|c|}
\hline \multirow[t]{2}{*}{ Strength } & \multirow{2}{*}{$\begin{array}{l}\text { Concentration } \\
\text { of diluted solution }\end{array}$} & \multicolumn{2}{|l|}{ Initial storage } & \multicolumn{2}{|c|}{ Subsequent storage } \\
\hline & & Temperature & $\begin{array}{l}\text { Time interval } \\
\text { (days) }\end{array}$ & Temperature & $\begin{array}{l}\text { Time interval } \\
\text { (hours) }\end{array}$ \\
\hline \multirow[t]{5}{*}{$0.5 \mathrm{mg}$ vial } & $3000 \mathrm{ng} / \mathrm{mL}$ & $5^{\circ} \mathrm{C}$ & $0,1,8$ & - & - \\
\hline & & $5^{\circ} \mathrm{C}$ & $\mathrm{I}$ & $25^{\circ} \mathrm{C}$ & 24,48 \\
\hline & & & & $30^{\circ} \mathrm{C}$ & 24,48 \\
\hline & & $5^{\circ} \mathrm{C}$ & 8 & $25^{\circ} \mathrm{C}$ & 24,48 \\
\hline & & & & $30^{\circ} \mathrm{C}$ & 24,48 \\
\hline \multirow[t]{5}{*}{$1.5 \mathrm{mg}$ vial } & $15,000 \mathrm{ng} / \mathrm{mL}$ and & $5^{\circ} \mathrm{C}$ & $0,1,8$ & - & - \\
\hline & $60,000 \mathrm{ng} / \mathrm{mL}$ & $5^{\circ} \mathrm{C}$ & I & $25^{\circ} \mathrm{C}$ & 24,48 \\
\hline & & & & $30^{\circ} \mathrm{C}$ & 24,48 \\
\hline & & $5^{\circ} \mathrm{C}$ & 8 & $25^{\circ} \mathrm{C}$ & 24,48 \\
\hline & & & & $30^{\circ} \mathrm{C}$ & 24,48 \\
\hline
\end{tabular}

Abbreviation: AS, arginine-sucrose. 
microbial population increased by more than $0.5 \log _{10}$ of the initial inoculum.

\section{Results}

\section{Stability}

Potency (relative to initial potency at time zero) of the reconstituted and stored epoprostenol AS 0.5 and $1.5 \mathrm{mg}$ vial at $5^{\circ} \mathrm{C}$ remained near $100 \%$ for both diluents even after 7 days of storage. For the reconstituted $0.5 \mathrm{mg}$ vial, potency was $>90 \%$ after 4 days of storage at $25^{\circ} \mathrm{C}$ for both diluents.
Stability after 4 days of storage at $25^{\circ} \mathrm{C}$ was not tested for the reconstituted $1.5 \mathrm{mg}$ vial; however, potency was $89 \%$ after 7 days at $25^{\circ} \mathrm{C}$ and therefore was likely to have been $>90 \%$ after 4 days.

The potency over time of the reconstituted and immediately diluted solutions of epoprostenol AS at different temperatures is shown in Figure $1 \mathrm{~A}-\mathrm{C}$. Potency was not dependent on diluents, but was dependent on temperature and concentration. For dilutions of $3000 \mathrm{ng} / \mathrm{mL}$, potency was $>90 \%$ after 48,24 , and 8 hours at $25^{\circ} \mathrm{C}, 30^{\circ} \mathrm{C}$, and
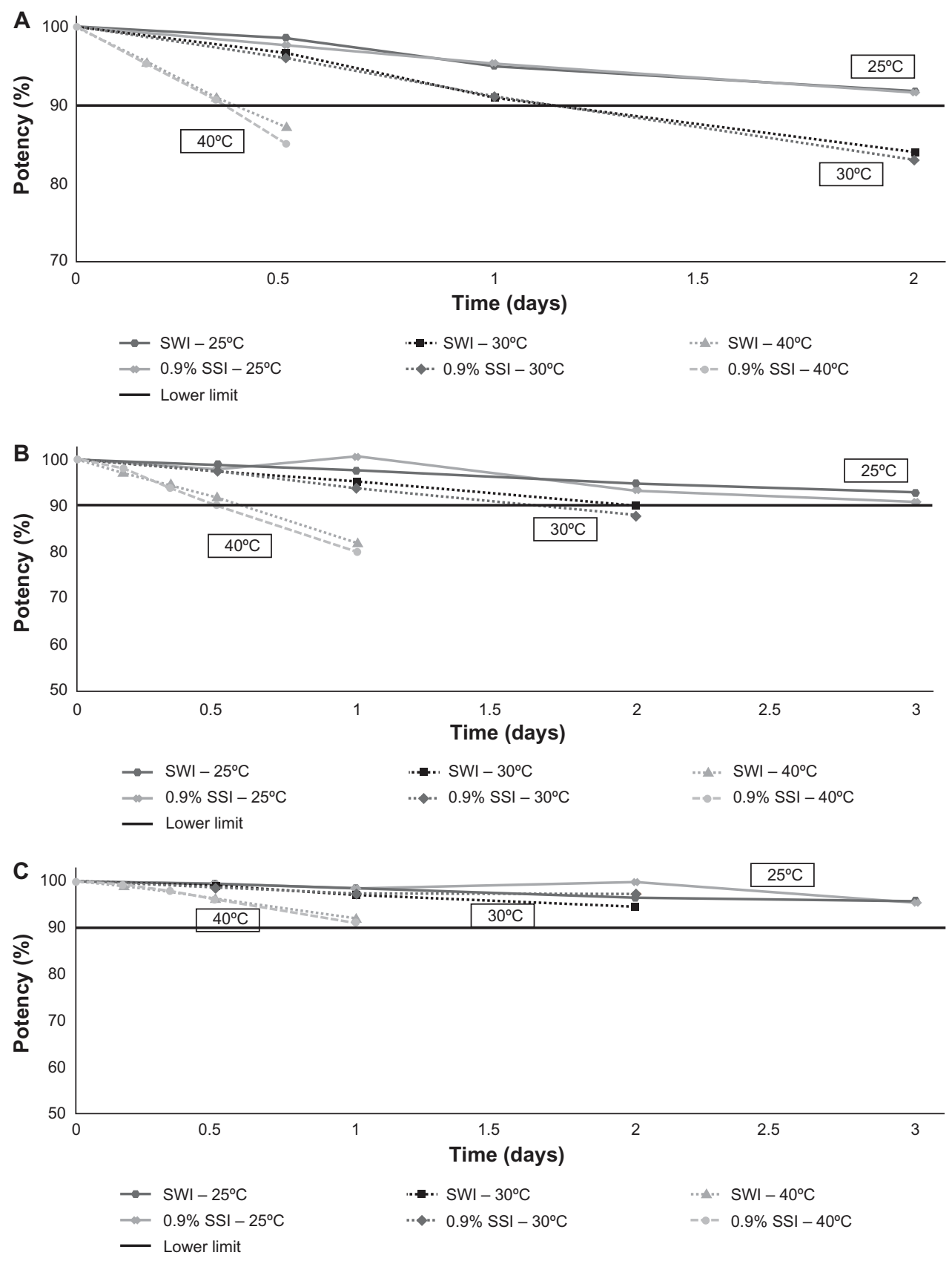

Figure I Potency of epoprostenol AS solutions diluted in SSI or SWI. (A) $3000 \mathrm{ng} / \mathrm{mL}$. (B) $15,000 \mathrm{ng} / \mathrm{mL}$. (C) $60,000 \mathrm{ng} / \mathrm{mL}$. Abbreviations: AS, arginine-sucrose; SSI, sterile saline for injection; SWI, sterile water for injection. 
$40^{\circ} \mathrm{C}$, respectively. For dilutions of $15,000 \mathrm{ng} / \mathrm{mL}$, potency was $>90 \%$ after 72,24 , and 12 hours at $25^{\circ} \mathrm{C}, 30^{\circ} \mathrm{C}$, and $40^{\circ} \mathrm{C}$, respectively. For dilutions of $60,000 \mathrm{ng} / \mathrm{mL}$, potency was $>90 \%$ after 72,48 , and 24 hours for $25^{\circ} \mathrm{C}, 30^{\circ} \mathrm{C}$, and $40^{\circ} \mathrm{C}$, respectively.

The potency of reconstituted and diluted epoprostenol AS stored at $5^{\circ} \mathrm{C}$ for 1 or 8 days and subsequently stored for 24 or 48 hours either at $25^{\circ} \mathrm{C}$ or $30^{\circ} \mathrm{C}$ is shown in Figures $2 \mathrm{~A}$ and $\mathrm{B}$ (3000 ng/mL), 3A and B $(15,000 \mathrm{ng} / \mathrm{mL})$, and $4 \mathrm{~A}$ and $\mathrm{B}$ $(60,000 \mathrm{ng} / \mathrm{mL})$. Potency was not dependent on diluents. For $3000 \mathrm{ng} / \mathrm{mL}$, potency remained close to $100 \%$ after 8 days at $5^{\circ} \mathrm{C}$, and above $90 \%$ if this was followed by 24 hours at $25^{\circ} \mathrm{C}$ or $30^{\circ} \mathrm{C}$. For $15,000 \mathrm{ng} / \mathrm{mL}$, the potency was $>98 \%$ after 8 days at $5^{\circ} \mathrm{C}$ and $>92 \%$ if followed by 24 hours at $25^{\circ} \mathrm{C}$ or $30^{\circ} \mathrm{C}$. For $60,000 \mathrm{ng} / \mathrm{mL}$, the potency was $>98 \%$ after 8 days at $5^{\circ} \mathrm{C}$ and $>95 \%$ if followed by 24 hours at $25^{\circ} \mathrm{C}$ or $30^{\circ} \mathrm{C}$ and $>93 \%$ if followed by 48 hours at $25^{\circ} \mathrm{C}$ or $30^{\circ} \mathrm{C}$.

Overall, the $\mathrm{pH}$ of the diluted solutions ranged from 10.8 to 11.9 , with the lowest $\mathrm{pH}$ in the $3000 \mathrm{ng} / \mathrm{mL}$ solution and the highest in the $60,000 \mathrm{ng} / \mathrm{mL}$ solution. Variation in $\mathrm{pH}$ of the diluted solutions was minimal during storage and did not show any temporal pattern. $\mathrm{pH}$ ranges were as follows: $3000 \mathrm{ng} / \mathrm{mL} 11.0-11.1$ (sterile water for injection) and 10.8-11.0 (sterile saline for injection); $15,000 \mathrm{ng} / \mathrm{mL}$ 11.0-11.5 (sterile water for injection) and 11.1-11.4 (sterile saline for injection); 60,000 ng/mL 11.3-12.0 (sterile water for injection) and 11.3-11.9 (sterile saline for injection).
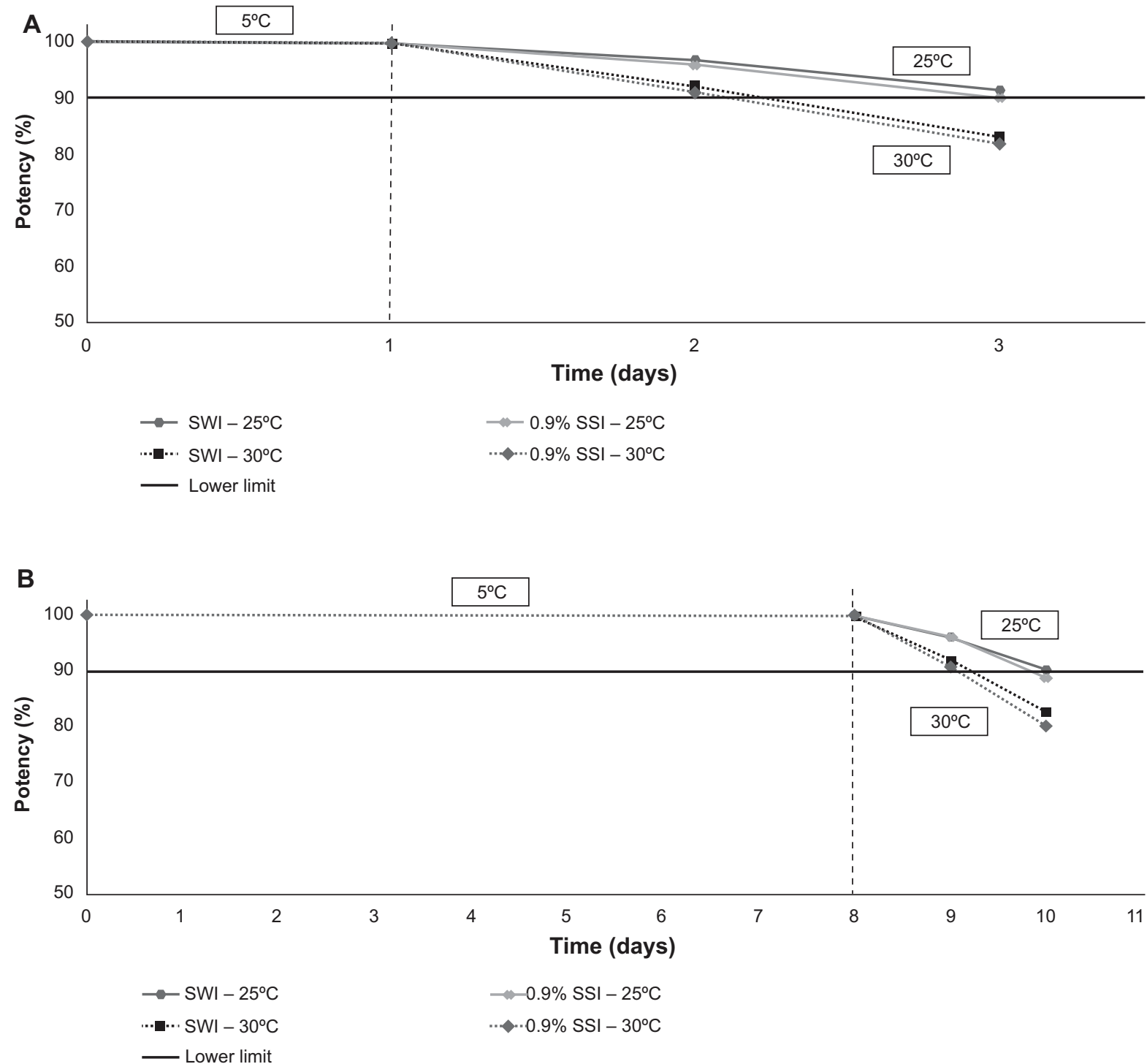

Figure 2 Potency of epoprostenol AS at $3000 \mathrm{ng} / \mathrm{mL}$ diluted in SSI or SWI. (A) After one day of storage at $5^{\circ} \mathrm{C}$ followed by subsequent storage at $25^{\circ} \mathrm{C}$ or $30^{\circ} \mathrm{C}$. (B) After 8 days of storage at $5^{\circ} \mathrm{C}$ followed by exposure to $25^{\circ} \mathrm{C}$ or $30^{\circ} \mathrm{C}$.

Abbreviations: AS, arginine-sucrose; SSI, sterile saline for injection; SWI, sterile water for injection. 

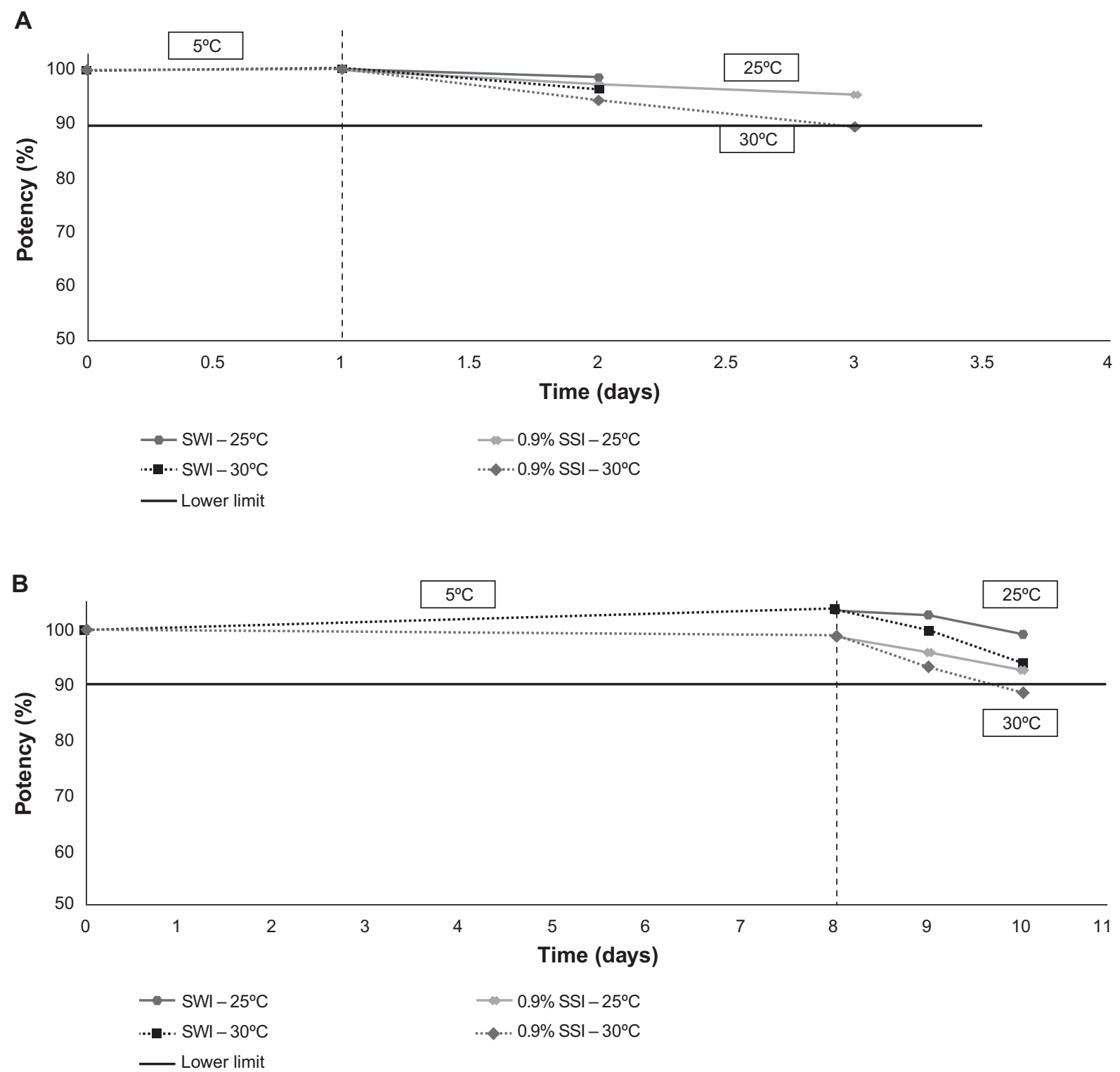

Figure 3 Potency of epoprostenol AS $15,000 \mathrm{ng} / \mathrm{mL}$ diluted in SSI or SWI. (A) After one day of storage at $5^{\circ} \mathrm{C}$ followed by exposure to $25^{\circ} \mathrm{C}$ or $30^{\circ} \mathrm{C}$. (B) After 8 days of storage at $5^{\circ} \mathrm{C}$ followed by exposure to $25^{\circ} \mathrm{C}$ or $30^{\circ} \mathrm{C}$.

Abbreviations: AS, arginine-sucrose; SSI, sterile saline for injection; SWI, sterile water for injection.

\section{Effectiveness of preservative}

At the extremes of testing (days 0 and 14), no growth of any inoculum in either diluent was seen in reconstituted epoprostenol AS under any of the storage conditions tested (Table 3). For the $3000 \mathrm{ng} / \mathrm{mL}$ solution of the new formulation epoprostenol AS diluted with sterile water for injection, some microbial proliferation was recorded for C. sporogenes after 16 days at $5^{\circ} \mathrm{C}$ and 48 hours at $25^{\circ} \mathrm{C}$ (Table 4). This is far longer than the recommended shelf-life for any concentrations of epoprostenol AS. No growth of any inoculum was seen in solutions of either diluent over the full course of the study under any of the other storage conditions tested, including 16 days at $5^{\circ} \mathrm{C}$ followed by a further
24 hours at $25^{\circ} \mathrm{C}$. Data are only shown for the extremes of testing at 0 and 16 days of storage (Table 4).

\section{Discussion}

This study describes the improved stability of epoprostenol AS relative to that previously reported for both epoprostenol GM and epoprostenol AM. ${ }^{1}$ Following reconstitution, the stability of epoprostenol AS was assessed at room temperature and $30^{\circ} \mathrm{C}$ subsequent to dilution or to dilution and storage at $5^{\circ} \mathrm{C}$. The range of test conditions used was representative of routine clinical use, ie, immediate administration of the diluted solution at room temperature from freshly made up or stored reconstituted solution, 

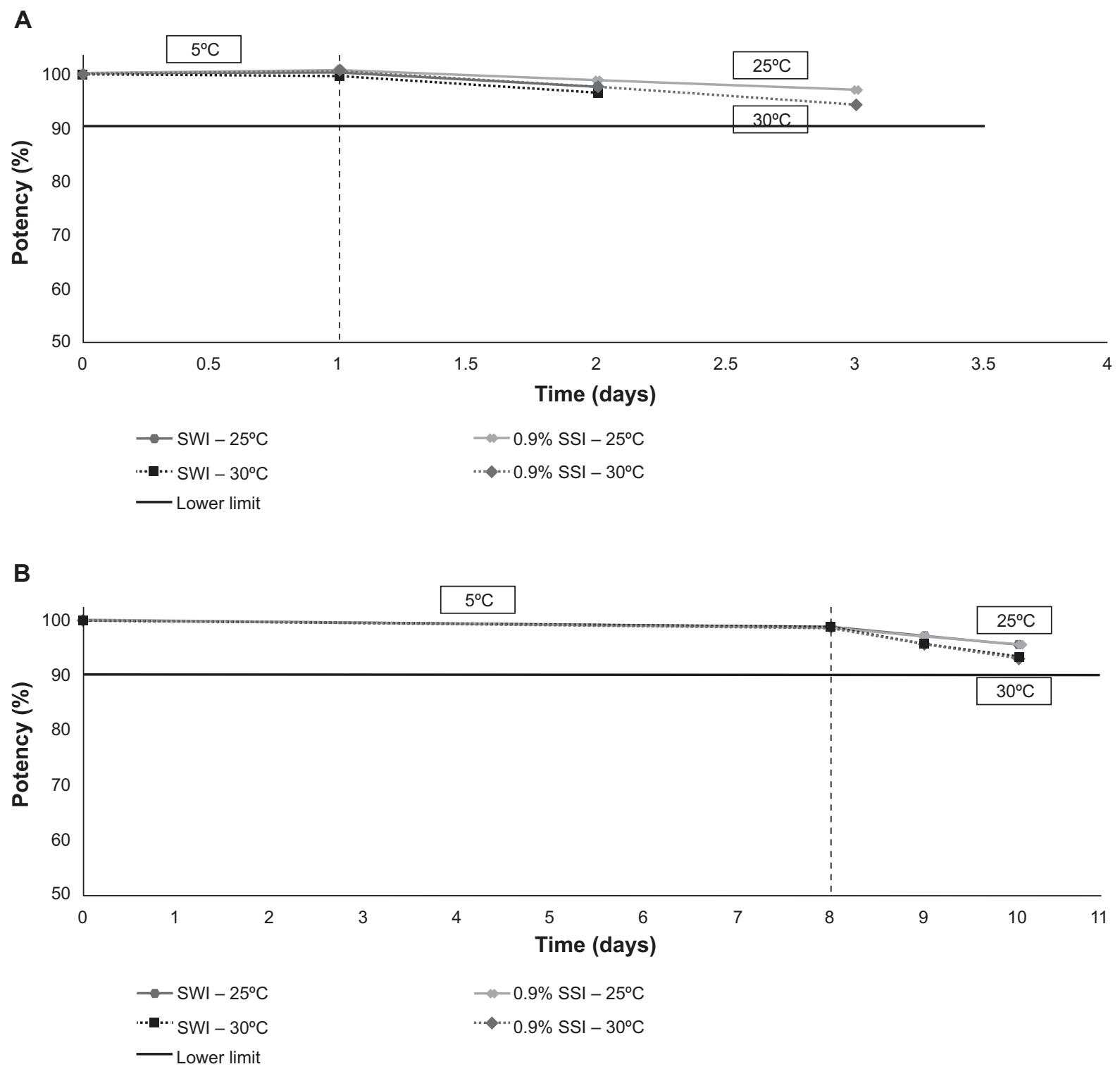

Figure 4 Stability of epoprostenol AS at $60,000 \mathrm{ng} / \mathrm{mL}$ diluted in SSI or SWI. (A) After one day of storage at $5^{\circ} \mathrm{C}$ followed by exposure to $25^{\circ} \mathrm{C}$ or $30^{\circ} \mathrm{C}$. (B) After 8 days of storage at $5^{\circ} \mathrm{C}$ followed by exposure to $25^{\circ} \mathrm{C}$ or $30^{\circ} \mathrm{C}$.

Abbreviations: AS, arginine-sucrose; SSI, sterile saline for injection; SWI, sterile water for injection.

or administration of the diluted solution previously kept refrigerated. Microbiological testing, for reconstituted and diluted solutions, was also conducted across a time period that reflected the demonstrated stability of the product and its likely clinical use. Although only the lowest dilution of epoprostenol AS was used for microbiological testing, this represents a "worst case" scenario because the $\mathrm{pH}$ of the diluted solution is lower at lower concentrations, and so more favorable for the growth of the micro-organisms tested.

While it is recommended that diluted solutions of epoprostenol GM be used immediately, solutions can be stored prior to use under refrigerated conditions $\left(2^{\circ} \mathrm{C}-8^{\circ} \mathrm{C}\right)$. According to the European Union Summary of Product
Characteristics, ${ }^{5}$ diluted solutions of epoprostenol GM can be refrigerated for a maximum of one day prior to use, provided the solution is then used over a one-day period, with ice packs changed as necessary to maintain a temperature of $2^{\circ} \mathrm{C}-8^{\circ} \mathrm{C}$. If ice packs cannot be used, then the maximum time of use at room temperature for prestored solutions is 8 hours. ${ }^{5}$ For freshly reconstituted and diluted solutions, the maximum time of use at room temperature is 12 hours.

The improved stability of the original formulation of epoprostenol AM allows for reconstituted solutions to be stored for up to 5 days when refrigerated or up to 2 days at room temperature. ${ }^{1}$ After reconstitution followed by immediate dilution to final concentration, diluted solutions of $6000 \mathrm{ng} / \mathrm{mL}$ or 
Table 3 Preservative effectiveness testing for reconstituted epoprostenol AS stored at $5^{\circ} \mathrm{C}$ and $25^{\circ} \mathrm{C}$ for 0 and 14 days (log reduction in count $\left.\mathrm{t}^{\mathrm{a}}\right)$

\begin{tabular}{|c|c|c|c|c|c|c|c|c|}
\hline & \multicolumn{4}{|l|}{ SSI } & \multicolumn{4}{|l|}{ SWI } \\
\hline & \multicolumn{2}{|l|}{$\overline{5^{\circ} \mathrm{C}}$} & \multicolumn{2}{|l|}{$25^{\circ} \mathrm{C}$} & \multicolumn{2}{|l|}{$5^{\circ} \mathrm{C}$} & \multicolumn{2}{|l|}{$25^{\circ} \mathrm{C}$} \\
\hline & Day 0 & Day 14 & Day 0 & Day 14 & Day 0 & Day 14 & Day 0 & Day 14 \\
\hline S. aureus & $>0.30$ & $>0.30$ & $>0.30$ & $>0.30$ & $>0.60$ & $>0.60$ & $>0.60$ & $>0.60$ \\
\hline P. aeruginosa & $>0.30$ & $>0.30$ & $>0.30$ & $>0.30$ & $>0.30$ & $>0.30$ & $>0.30$ & $>0.30$ \\
\hline E. coli & $>0.60$ & $>0.60$ & $>0.60$ & $>0.60$ & $>0.60$ & $>0.60$ & $>0.60$ & $>0.60$ \\
\hline C. albicans & 0.48 & $>0.48$ & $>0.48$ & $>0.48$ & -0.12 & $>0.48$ & 0.48 & $>0.48$ \\
\hline A. niger & -0.22 & $>0.48$ & $>0.48$ & $>0.48$ & -0.12 & $>0.78$ & 0.18 & $>0.78$ \\
\hline C. sporogenes & 0.00 & 0.00 & 0.00 & 0.00 & 0.00 & 0.00 & 0.00 & 0.00 \\
\hline
\end{tabular}

Notes: ${ }^{2} \mathrm{Log}$ reduction in the number of CFU relative to the initial inoculation. Negative numbers therefore indicate an increase in CFU over the initial inoculum. Increases in CFU $>0.5 \log$ relative to the initial inoculums were considered as "no increase".

Abbreviations: AS, arginine-sucrose; SSI, sterile saline (sodium chloride 0.9\%) for injection; SWI, sterile water for injection; CFU, colony forming unit; S. aureus, Staphylococcus aureus; P. aeruginosa, Pseudomonas aeruginosa; E. coli, Escherichia coli; C. albicans, Candida albicans; A. niger, Aspergillus niger; C. sporogenes, Clostridium sporogenes.

above may be used for a day at room temperature (12 hours for lower concentrations), and therefore administration does not require use of ice packs. Longer storage periods and the ability to infuse at room temperature without the need to change reservoirs every 8 hours represents an improvement in convenience for physicians, patients, and caregivers. Based on the data from this study, epoprostenol AS may be expected to improve convenience further and have a positive impact on patient quality of life. Convenience is further improved by the ability to reconstitute and dilute epoprostenol AS in easily available sterile water for injection or sterile saline for injection, rather than the proprietary diluents required for epoprostenol GM.

The high $\mathrm{pH}$ of the reconstituted solution is likely to be a major contributor to the improved stability of epoprostenol AS. The vinyl ether moiety of epoprostenol is best stabilized in basic solutions ( $>\mathrm{pH} 8.8$ ), and high $\mathrm{pH}$ solutions $(>\mathrm{pH} 10)$ have been used to stabilize prostacyclin, for example, to enable extraction from whole blood. ${ }^{7}$ This is probably due to the reduced levels of hydronium ions in more alkaline solutions, because hydrolysis of epoprostenol is catalyzed by the hydronium ion. ${ }^{8}$ While epoprostenol GM uses a glycine buffer which results in a $\mathrm{pH}$ of $10.2-10.8,{ }^{6}$ epoprostenol AS uses an arginine buffer, which provides a higher $\mathrm{pH}$ due to the fact that the guanidine group of arginine has a particularly high $\mathrm{pKa}$ (13.2), whereas the highest $\mathrm{pKa}$ value for the $\alpha$-amino group of glycine is 9.8 . Therefore, arginine is more suitable for providing a high alkaline environment and better $\mathrm{pH}$ control upon dilution in intravenous diluents. The further improvement in stability seen with epoprostenol AS relative to epoprostenol AM may be due to the fact that the new formulation is buffered to a higher $\mathrm{pH}$ compared with the original formulation. Epoprostenol AS is buffered to match the $\mathrm{pKa}$ of the arginine buffer. The $\mathrm{pH}$ of reconstituted epoprostenol AS is $>12$. In the current study, the $\mathrm{pH}$ of diluted epoprostenol AS ranged from 10.8-11.9, compared with 9.9-11.3 for epoprostenol $\mathrm{AM}^{1}$ and $10.2-10.8$ for diluted epoprostenol GM. ${ }^{6}$ Arginine is widely used to prevent protein

Table 4 Preservative effectiveness testing for diluted epoprostenol AS $(3000 \mathrm{ng} / \mathrm{mL})$ stored for 0 days at $5^{\circ} \mathrm{C}$ and 16 days $5^{\circ} \mathrm{C}$ plus 24 or 48 hours at $25^{\circ} \mathrm{C}\left(\log\right.$ reduction in count $\left.{ }^{\mathrm{a}}\right)$

\begin{tabular}{|c|c|c|c|c|c|c|}
\hline & \multicolumn{3}{|l|}{ SSI } & \multicolumn{3}{|l|}{ SWI } \\
\hline & $\begin{array}{l}0 \text { hours } \\
\text { at } 5^{\circ} \mathrm{C}\end{array}$ & $\begin{array}{l}16 \text { days at } 5^{\circ} \mathrm{C}+ \\
24 \text { hours at } 25^{\circ} \mathrm{C}\end{array}$ & $\begin{array}{l}16 \text { days at } 5^{\circ} \mathrm{C}+ \\
48 \text { hours at } 25^{\circ} \mathrm{C}\end{array}$ & $\begin{array}{l}0 \text { hours } \\
\text { at } 5^{\circ} \mathrm{C}\end{array}$ & $\begin{array}{l}16 \text { days at } 5^{\circ} \mathrm{C}+ \\
24 \text { hours at } 25^{\circ} \mathrm{C}\end{array}$ & $\begin{array}{l}16 \text { days at } 5^{\circ} \mathrm{C}+ \\
48 \text { hours at } 25^{\circ} \mathrm{C}\end{array}$ \\
\hline S. aureus & 0.30 & $>0.30$ & $>0.30$ & 0.12 & $>0.60$ & $>0.60$ \\
\hline P. aeruginosa & $>0.30$ & $>0.30$ & $>0.30$ & $>0.30$ & $>0.30$ & $>0.30$ \\
\hline E. coli & 0.60 & $>0.60$ & $>0.60$ & 0.60 & $>0.60$ & $>0.60$ \\
\hline C. albicans & 0.00 & $>0.48$ & $>0.48$ & 0.18 & $>0.48$ & $>0.48$ \\
\hline A. niger & -0.30 & $>0.48$ & $>0.48$ & 0.08 & $>0.78$ & $>0.78$ \\
\hline C. sporogenes & 0.00 & 0.00 & 0.00 & 0.00 & -0.30 & -0.60 \\
\hline
\end{tabular}

Notes: a Log reduction in the number of CFU relative to the initial inoculation. Negative numbers therefore indicate an increase in CFU over the initial inoculum. Increases in CFU > 0.5 log relative to the initial inoculums were considered as "no increase".

Abbreviations: AS, arginine-sucrose; SSI, sterile saline (sodium chloride 0.9\%) for injection; SWI, sterile water for injection; CFU, colony forming unit; S. aureus, Staphylococcus aureus; P. aeruginosa, Pseudomonas aeruginosa; E. coli, Escherichia coli; C. albicans, Candida albicans; A. niger, Aspergillus niger; C. sporogenes, Clostridium sporogenes. 
degradation in aqueous solution because of its ability to suppress protein aggregation. ${ }^{9}$ Theoretically, the improved stability of epoprostenol AS may be linked to the presence of multiple ionic binding sites on the arginine molecule (guanidine amine and secondary amine). These could potentially form an ionic cluster with multiple molecules of epoprostenol, thereby creating a sterically protective environment and so decreasing the rate of hydrolysis. However, whether this mechanism contributes to the extended stability of epoprostenol AS relative to epoprostenol GM remains unknown.

The replacement of mannitol with sucrose improves the stability and appearance of the lyophilized product. This is linked to the glass transition temperature $(\mathrm{Tg})$ of the drug product. With mannitol, the Tg of the final product is around $30^{\circ} \mathrm{C}$, which results in a transition from the glassy state to the amorphous state in time. The $\mathrm{Tg}$ of sucrose is around $40^{\circ} \mathrm{C}$.

This study showed that, apart from one microbe (C. sporogenes) under one extreme test condition (16 days storage at $5^{\circ} \mathrm{C}$ plus 2 days at $25^{\circ} \mathrm{C}$ ), there was no microbial growth of the tested organisms in either reconstituted solution or $3000 \mathrm{ng} / \mathrm{mL}$ diluted solutions of epoprostenol AS. The micro-organisms tested represent a broad spectrum of potential manufacturing, nosocomial and household contaminants, including Gram-negative and Gram-positive bacteria, common fungi and molds, as per the United States Pharmacopeia 51 antimicrobial effectiveness test. Epoprostenol AS, when reconstituted and diluted, therefore does not support the growth of micro-organisms, making it a self-preserving system. This self-preservation is likely to result from the high $\mathrm{pH}$ of the amino acid buffer used in epoprostenol AS, as discussed previously, which provided adverse conditions for relevant microbiological growth.

\section{Recommended shelf-life}

Based on the stability and preservative effectiveness data from this study, the following recommendations for shelf-life can be made for epoprostenol AS, depending on concentration and conditions of use. For immediate use following reconstitution and dilution to $3000 \mathrm{ng} / \mathrm{mL}$, the maximum shelf-life is 48 hours at $25^{\circ} \mathrm{C}$ including short excursions (up to 2 hours) at $40^{\circ} \mathrm{C}$, or 24 hours at $30^{\circ} \mathrm{C}$ including short excursions (up to 2 hours) at $40^{\circ} \mathrm{C}$ or 8 hours at $40^{\circ} \mathrm{C}$. For immediate use following reconstitution and dilution to $15,000 \mathrm{ng} / \mathrm{mL}$, the maximum shelf-life is 48 hours at $25^{\circ} \mathrm{C}$ including short excursions (up to 4 hours) at $40^{\circ} \mathrm{C}$, or 24 hours at $30^{\circ} \mathrm{C}$ including short excursions (up to 4 hours)
Table 5 Shelf-lives and storage conditions for epoprostenol AS for clinical administration after several days of storage of the reconstituted solution

\begin{tabular}{lll}
\hline Concentration & $\begin{array}{l}\text { Condition of storage } \\
\text { of reconstituted } \\
\text { solution }\end{array}$ & $\begin{array}{l}\text { Maximum } \\
\text { shelf-life of diluted } \\
\text { solution (hours) }\end{array}$ \\
\hline$\geq 3000 \mathrm{ng} / \mathrm{mL}$ and & 7 days at $5^{\circ} \mathrm{C}$ & 24 at $25^{\circ} \mathrm{C}^{\text {a }}$ \\
$<15,000 \mathrm{ng} / \mathrm{mL}$ & OR & 12 at $30^{\circ} \mathrm{C}^{\text {a }}$ \\
& I day at $25^{\circ} \mathrm{C}$ & 8 at $40^{\circ} \mathrm{C}$ \\
$15,000 \mathrm{ng} / \mathrm{mL}$ and & 7 days at $5^{\circ} \mathrm{C}$ & 48 at $25^{\circ} \mathrm{C}^{\text {a }}$ \\
$<60,000 \mathrm{ng} / \mathrm{mL}$ & OR & 24 at $30^{\circ} \mathrm{C}^{\text {a }}$ \\
& I day at $25^{\circ} \mathrm{C}$ & 8 at $40^{\circ} \mathrm{C}$ \\
$\geq 60,000 \mathrm{ng} / \mathrm{mL}$ & 7 days at $5^{\circ} \mathrm{C}$ & 72 at $25^{\circ} \mathrm{C}^{\text {a }}$ \\
& OR & 48 at $30^{\circ} \mathrm{C}$ \\
& I day at $25^{\circ} \mathrm{C}$ & 24 at $40^{\circ} \mathrm{C}$ \\
\hline
\end{tabular}

Notes: a Each recommendation includes a short excursion at $40^{\circ} \mathrm{C}$ for up to 2 hours for concentration below $15,000 \mathrm{ng} / \mathrm{mL}$, up to 4 hours for a concentration between $15,000 \mathrm{ng} / \mathrm{mL}$, and $60,000 \mathrm{ng} / \mathrm{mL}$ and up to 8 hours for concentration above $60,000 \mathrm{ng} / \mathrm{mL}$

Abbreviation: AS, arginine-sucrose.

at $40^{\circ} \mathrm{C}$, or 12 hours at $40^{\circ} \mathrm{C}$. For immediate use following reconstitution and dilution to $60,000 \mathrm{ng} / \mathrm{mL}$, the maximum shelf-life is 72 hours at $25^{\circ} \mathrm{C}$ including excursions (up to 8 hours) at $40^{\circ} \mathrm{C}, 48$ hours at $30^{\circ} \mathrm{C}$ including excursions (up to 8 hours) at $40^{\circ} \mathrm{C}$, and 24 hours $40^{\circ} \mathrm{C}$.

By combining the data for diluted solutions with those obtained for the reconstituted solution, recommendations for the shelf-life of epoprostenol AS diluted for administration following several days of storage of the reconstituted solution can also be made (Table 5). Recommended shelf-lives based on storage conditions for epoprostenol AS administration after several days of storage of the diluted solution are given in Table 6. Key comparisons between use and storage conditions of epoprostenol AM and epoprostenol AS are presented in Table 7.

Table 6 Shelf-lives and storage conditions for epoprostenol AS for clinical administration after several days of storage of the diluted solution

\begin{tabular}{lll}
\hline Concentration & $\begin{array}{l}\text { Condition of } \\
\text { storage of diluted } \\
\text { solution }\end{array}$ & $\begin{array}{l}\text { Maximum shelf-life } \\
\text { of diluted solution } \\
\text { (hours) }\end{array}$ \\
\hline$\geq 3000 \mathrm{ng} / \mathrm{mL}$ and & $\leq 8$ days at $5^{\circ} \mathrm{C}$ & 24 at $25^{\circ} \mathrm{C}^{\mathrm{a}}$ \\
$<15,000 \mathrm{ng} / \mathrm{mL}$ & & 24 at $30^{\circ} \mathrm{C}^{\text {a }}$ \\
$\geq 15,000 \mathrm{ng} / \mathrm{mL}$ and & $\leq 8$ days at $5^{\circ} \mathrm{C}$ & 48 at $25^{\circ} \mathrm{C}^{\text {a }}$ \\
$<60,000 \mathrm{ng} / \mathrm{mL}$ & & 24 at $30^{\circ} \mathrm{C}^{\text {a }}$ \\
$\geq 60,000 \mathrm{ng} / \mathrm{mL}$ & $\leq 8$ days at $5^{\circ} \mathrm{C}$ & 48 at $25^{\circ} \mathrm{C}^{\text {a }}$ \\
& & 48 at $30^{\circ} \mathrm{C}^{\text {a }}$ \\
\hline
\end{tabular}

Notes: ${ }^{a}$ Each recommendation includes a short excursion at $40^{\circ} \mathrm{C}$ for up to 2 hours for concentration below $15,000 \mathrm{ng} / \mathrm{mL}$, up to 4 hours for a concentration between $15,000 \mathrm{ng} / \mathrm{mL}$ and $60,000 \mathrm{ng} / \mathrm{mL}$, and up to 8 hours for concentration above $60,000 \mathrm{ng} / \mathrm{mL}$.

Abbreviation: AS, arginine-sucrose. 
Table 7 Key comparisons between use and storage conditions of epoprostenol AM and epoprostenol AS

\begin{tabular}{lll}
\hline Conditions & Epoprostenol AM & Epoprostenol AS \\
\hline Immediate use at $25^{\circ} \mathrm{C}$ & $\geq 3000$ and $<6000 \mathrm{ng} / \mathrm{mL}: 12$ hours & $\geq 3000$ and $<15,000 \mathrm{ng} / \mathrm{mL}: 48$ hours \\
& $\geq 6000$ and $<30,000 \mathrm{ng} / \mathrm{mL}: 24$ hours & $\geq 15,000$ and $<60,000 \mathrm{ng} / \mathrm{mL}: 48 \mathrm{hours}$ \\
& $\geq 30,000 \mathrm{ng} / \mathrm{mL}: 72$ hours & $\geq 60,000 \mathrm{ng} / \mathrm{mL}: 72 \mathrm{hours}$ \\
No & & $\geq 3,000$ and $<15,000 \mathrm{ng} / \mathrm{mL}: 24 \mathrm{hours}$ \\
& & $\geq 15,000$ and $<60,000 \mathrm{ng} / \mathrm{mL}: 24 \mathrm{hours}$ \\
& 7 days at $2^{\circ} \mathrm{C}-8^{\circ} \mathrm{C}$ followed at $25^{\circ} \mathrm{C}$ by & $\geq 60,000 \mathrm{ng} / \mathrm{mL}: 48 \mathrm{hours}$ \\
After storage of the diluted & $\geq 3000$ and $<9000 \mathrm{ng} / \mathrm{mL}:$ no & 8 days at $2^{\circ} \mathrm{C}-8^{\circ} \mathrm{C}$ followed at $25^{\circ} \mathrm{C}$ by \\
solution at $2{ }^{\circ} \mathrm{C}-8^{\circ} \mathrm{C}$ & $\geq 9000$ and $<30,000 \mathrm{ng} / \mathrm{mL}: 12$ hours & $\geq 3000$ and $<15,000 \mathrm{ng} / \mathrm{mL}: 24$ hours \\
& $\geq 30,000 \mathrm{ng} / \mathrm{mL}: 24$ hours & $\geq 15,000$ and $<60,000 \mathrm{ng} / \mathrm{mL}: 48 \mathrm{hours}$ \\
& & $\geq 60,000 \mathrm{ng} / \mathrm{mL}: 48 \mathrm{hours}$
\end{tabular}

Abbreviations: AM, arginine-mannitol; AS, arginine-sucrose.

\section{Conclusion}

Epoprostenol AS reconstituted and diluted with either sterile water for injection or sterile saline for injection has superior stability compared with previous formulations of epoprostenol sodium. The immediate clinical implications of these findings are convenience for patients with pulmonary arterial hypertension and their physicians and caregivers as a result of elimination of the need for ice packs and stringent storage conditions. Better convenience may also result in improved quality of life for patients.

\section{Acknowledgments}

The authors would like to thank Roberta Bucci and Stefano Bovani (Patheon Italia SpA, Ferentino, Italy), and Anne Muller, Anne Schirmer, Elodie Barret, and Marta Polin (Actelion Pharmaceuticals Ltd, Allschwil, Switzerland) for their support with high-performance liquid chromatography measurements.

\section{Disclosure}

Both OL and DB are employees of Actelion Pharmaceuticals Ltd, manufacturer of both epoprostenol AM and epoprostenol
AS. Editorial assistance was provided by Lisa Thomas from Elements Communications Ltd, Westerham, UK, and funded by Actelion Pharmaceuticals Ltd.

\section{References}

1. Lambert O, Bandilla D, Iyer R, Witchey-Lakshmanan L, Palepu N. Stability and microbiological properties of a new formulation of epoprostenol sodium when reconstituted and diluted. Drug Design Dev Ther. 2012;6:61-70.

2. Farber HW, Loscalzo J. Pulmonary arterial hypertension. $N$ Engl J Med. 2004;351(16):1655-1665.

3. Humbert M, Sitbon O, Simonneau G. Treatment of pulmonary arterial hypertension. N Engl J Med. 2004;351(14):1425-1436.

4. Johnson RA, Lincoln FH, Thompson JL, et al. Synthesis and stereochemistry of prostacyclin and synthesis of 6-keto prostaglandin F-1 alpha. $J$ Am Chem Soc. 1977;99(12):4182-4184.

5. Flolan (epoprostenol sodium) for injection. Summary of Product Characteristics. Available from: http://www.medicines.org.uk/emc/ medicine/7173. Accessed September 12, 2011.

6. Flolan (epoprostenol sodium) for injection. Prescribing information. Available from: http://us.gsk.com/products/assets/us_flolan.pdf. Accessed September 12, 2011.

7. Skrinska V, Lucas FV. Isolation of prostacyclin from whole blood. Prostaglandins. 1981;22(3):365-375.

8. Cho MJ. Reduced hydrolytic lability of epoprostenol in the presence of cationic micelles. J Pharm Sci. 1982(4);71:453-454.

9. Shukla D, Trout BL. Interaction of arginine with proteins and the mechanism by which it inhibits aggregation. J Phys Chem B. 2010; 114(42):13426-13438.
Drug Design, Development and Therapy

\section{Publish your work in this journal}

Drug Design, Development and Therapy is an international, peerreviewed open-access journal that spans the spectrum of drug design and development through to clinical applications. Clinical outcomes, patient safety, and programs for the development and effective, safe, and sustained use of medicines are a feature of the journal, which

\section{Dovepress}

has also been accepted for indexing on PubMed Central. The manuscript management system is completely online and includes a very quick and fair peer-review system, which is all easy to use. Visit http://www.dovepress.com/testimonials.php to read real quotes from published authors. 